\title{
Interest of reference region models to monitor cancer treatment using dynamic contrast enhanced studies
}

\author{
F Frouin ${ }^{*}$, Z Zhang, ME Cohen, M Lefort, A de Cesare, C Pellot-Barakat, O Lucidarme \\ From International Cancer Imaging Society (ICIS) 14th Annual Teaching Course \\ Heidelberg, Germany. 9-11 October 2014
}

\begin{abstract}
Aim
Dynamic Contrast Enhanced (DCE) imaging is an investigative tool to monitor cancer treatments such as antiangiogenic drugs. The difficulty of estimating an appropriate arterial input function in MRI or ultrasound for instance makes the reference region (RR) model very attractive. However it is not applicable to hepatic perfusion studies for which two input functions (hepatic artery and portal vein) have to be considered. A generalization of the RR approach to hepatic DCE studies was thus developed and validated on DCE-CT hepatic studies for which both input functions could be estimated.
\end{abstract}

\section{Methods}

Our generalization of the RR approach for hepatic studies takes into account two reference regions in addition to the region of interest (or current voxel for parametric imaging). To validate the estimation of the perfusion parameters, numerical simulations were carried out. Ten DCE-CT studies (from five patients with hepatic cancerous lesions observed twice during the course of an antiangiogenic treatment) were also retrospectively analyzed.

\section{Results}

The simulations demonstrated the validity of the new RR model for both noise-free and noisy data. On CT data, perfusion parameters were close when using the two input functions or the new RR model (relative variations being generally less than $10 \%$ ). This experimental analysis gave also indications for the positioning of the two reference regions.

\footnotetext{
* Correspondence: frederique.frouin@inserm.fr
} Sorbonne Universités, Paris, France

(c) 2014 Frouin et al; licensee BioMed Central Ltd. This is an Open Access article distributed under the terms of the Creative Commons Biomed Central Attribution License (http://creativecommons.org/licenses/by/4.0), which permits unrestricted use, distribution, and reproduction in any medium, provided the original work is properly cited. The Creative Commons Public Domain Dedication waiver (http://creativecommons.org/publicdomain/zero/1.0/) applies to the data made available in this article, unless otherwise stated.

\section{and take full advantage of:}

- Convenient online submission

- Thorough peer review

- No space constraints or color figure charges

- Immediate publication on acceptance

- Inclusion in PubMed, CAS, Scopus and Google Scholar

- Research which is freely available for redistribution

Submit your manuscript at www.biomedcentral.com/submit 